\title{
Thymic alterations in mice deficient for the SNARE protein VAMP8/endobrevin
}

\author{
Namita Kanwar • Afshin Fayyazi • Bianca Backofen • \\ Mirko Nitsche • Ralf Dressel • \\ Gabriele Fischer von Mollard
}

Received: 25 March 2008 / Accepted: 2 September 2008 / Published online: 16 October 2008

(C) Springer-Verlag 2008

\begin{abstract}
SNARE (soluble- $N$-ethylmaleimide-sensitive factor attachment receptor) proteins mediate the recognition and fusion of transport vesicles in eukaryotic cells. The SNARE protein VAMP8 (also called endobrevin) is involved in the fusion of late endosomes and in some pathways of regulated exocytosis. In a subset of mice deficient for the SNARE protein VAMP8, a severe alteration of the thymus and in T lymphocyte development was observed and characterized. The size of the thymus and the number of thymocytes were dramatically reduced compared with those in heterozygous littermates. Further,
\end{abstract}

This work was supported by a Georg Christoph Lichtenberg Stipend from the Ministry for Science and Culture of Lower Saxony (to N.K.) and in part by grant MRTN-CT-2004-512253 (TRANS-NET) from the European Union (to R.D.).

N. Kanwar $\cdot$ B. Backofen · G. Fischer von Mollard $(\square)$

Biochemie III, Fakultät für Chemie, Universität Bielefeld,

33501 Bielefeld, Germany

e-mail: gabriele.mollard@uni-bielefeld.de

A. Fayyazi

Abteilung Pathologie, Universitätsmedizin Göttingen,

37099 Göttingen, Germany

\section{Nitsche}

Abteilung Strahlentherapie und Radioonkologie,

Universitätsmedizin Göttingen,

37099 Göttingen, Germany

\section{R. Dressel $(\square)$}

Abteilung Zelluläre und Molekulare Immunologie, Universitätsmedizin Göttingen,

37099 Göttingen, Germany

e-mail: rdresse@gwdg.de

Present address:

A. Fayyazi

Institut für Pathologie, Klinikum Pforzheim,

Pforzheim, Germany the compartmentalization into cortex and medulla and the organization of the thymus epithelium were disturbed. The numbers of all thymocyte subpopulations were reduced, with the CD4 and CD8 double-positive thymocytes being most severely affected. The proportion of proliferating thymocytes was reduced, and the staining of apoptotic cells in situ and ex vivo indicated an increased number of apoptotic cells. Isolated thymocytes of $\operatorname{Vamp} 8^{-/-}$mice were more susceptible to various apoptotic stimuli including glucocorticoids, FAS receptor, and CD3/CD28-mediated signaling in vitro, even before an increased number of apoptotic cells was detectable in situ. However, bone marrow of phenotypically affected $\operatorname{Vamp} 8^{-/-}$mice was readily able to repopulate immunodeficient hosts suggesting that the SNARE protein VAMP8 has a specific function in the thymic stroma affecting the proliferation and apoptosis of $\mathrm{T}$ lymphocytes during maturation in the thymus.

Keywords SNARE $\cdot$ T-cell $\cdot$ Thymus $\cdot$ Apoptosis .

Knockout mouse

\section{Introduction}

Eukaryotic cells contain membrane-enclosed compartments with specialized functions; these compartments are connected by membrane traffic via transport vesicles. Communication between cells is mediated by receptors on the plasma membrane and by the secretion of soluble signaling molecules. These proteins are transported to the cell surface via the endoplasmic reticulum, Golgi, and trans Golgi network. Signal transduction can be regulated by the endocytosis of cell surface receptors. These receptors can either be targeted from early endosomes via late endosomes 
to lysosomes for degradation (Perret et al. 2005) or recycled back to the cell surface for further signaling. In addition, endosomes can play an active role in certain signaling pathways because they contain specific signal transducers (Polo and Di Fiore 2006).

Complex protein machinery is required for recognition between transport vesicle and target membrane and the subsequent fusion of these membranes. SNAREs (soluble$\mathrm{N}$-ethylmaleimide-sensitive factor attachment protein receptor) play a key role in these processes (Jahn and Scheller 2006). The SNAREs found on transport vesicles and target membranes form complexes via their conserved SNARE motifs bridging the gap between both membranes and initiating membrane fusion. These SNARE complexes have a conserved structure consisting of four SNARE motifs forming an extended parallel bundle of four $\alpha$-helices (Sutton et al. 1998). Whereas most SNAREs contain a single SNARE motif, a few SNARE proteins such as SNAP23 and SNAP29 contribute two SNARE motifs to SNARE complexes. Specific SNARE complexes have been assigned to specific transport steps. Homotypic fusion of late endosomes is mediated by a SNARE complex composed of VAMP8 (also called endobrevin), vtilb, syntaxin 7, and syntaxin 8 in vitro (Antonin et al. 2000a). Transport from late endosomes to lysosomes requires vtilb, syntaxin 7, syntaxin 8, and VAMP7. VAMP7 replaces VAMP8 in this transport step (Pryor et al. 2004). Vamp $8^{-/-}$ mice are reported to have defects in regulated exocytosis of exocrine zymogen granules and other exocrine secretory granules (Wang et al. 2004, 2007). These data demonstrate that VAMP8 is required for exocytosis in the exocrine system in a complex with syntaxin 4 and SNAP23. VAMP8 is also involved in regulated exocytosis of dense granules, alpha granules, and lysosomes from platelets (Ren et al. 2007) and in secretion from mast cells (Lippert et al. 2007). Here, we have set out to extend studies of mice deficient for VAMP8. A particularly obvious phenotype is that these mice have an extremely small thymus. Therefore, we have concentrated our analysis of the effects of VAMP8 deficiency on thymus morphology and $\mathrm{T}$ lymphocyte development.

The thymus is responsible for the generation of $\mathrm{T}$ lymphocytes that respond to foreign antigens but not to self-antigens (Starr et al. 2003; Hogquist et al. 2005). Precursor cells from the bone marrow enter the thymus and undergo multiple and tightly regulated developmental steps, which include the rearrangement and expression of $\mathrm{T}$ cell receptor (TCR) genes, the positive selection of cells that can interact with self-major histocompatibility complex (MHC) molecules, and the negative selection of cells that strongly recognize self-antigens. The developing cells undergo phases of intense proliferation; however, about $98 \%$ of the thymocytes that develop in the thymus die by apoptosis because they do not meet the selection criteria (Egerton et al. 1990; Strasser and Bouillet 2003). The development of thymocytes depends on the interaction with stromal cells, which include epithelial cells, dendritic cells, macrophages, and fibroblasts. The thymocytes migrate during their development through multiple microenvironments in the cortex and medulla of the thymus (Takahama 2006). Each step in development is characterized by the expression of a specific set of cell surface molecules that can be used to analyze the T lymphocyte maturation. The most prominent stages are distinguished on the basis of CD4 and CD8 co-receptor expression. Immature $\mathrm{CD} 4^{-} \mathrm{CD} 8^{-}$double-negative (DN) thymocytes transiently become $\mathrm{CD} 4^{+} \mathrm{CD} 8^{+}$double-positive (DP) thymocytes before $\mathrm{CD}^{+}$or $\mathrm{CD} 8^{+}$single-positive (SP) T lymphocytes are generated that subsequently leave the thymus and enter the circulation. Multiple signaling events are involved in the maturation of $\mathrm{T}$ lymphocytes in which the amplitude and duration of signaling is often the key factor for the outcome, i.e., proliferation and progress in maturation or cell death by apoptosis. These signaling pathways are controlled by intracellular enzymes, regulatory proteins, adaptor molecules, transcription factors, and cell surface receptors. The subcellular organization of these signaling pathways could also depend on the function of the SNARE protein machinery.

We show herein that the cytoarchitecture of the thymus and subsequently the $\mathrm{T}$ lymphocyte development is severely disturbed in a subset of VAMP8-deficient mice. The apoptosis of thymocytes increases, and their proliferation decreases. This is the first description of a SNARE protein deficiency leading to severe alterations of the organization of thymic epithelial cells (TEC) and T cell development.

\section{Materials and methods}

Mice and genotyping

Vamp $8^{\text {tm1Lex }}$ (OST20346; Zambrowicz et al. 1998) were maintained on a mixed genetic background of $129 \mathrm{SvJ}$ and C57BL/6 strains. Heterozygous animals were used for breeding. All animal experiments were approved by the local government and were in accordance with institutional guidelines for the welfare of animals. Heterozygous littermates were always used as controls for the knockout mice. Between day 5 and day 16 after birth, the weight and health status of the $V a m p 8^{-1-}$ mice were recorded daily to document the phenotype of individual mice. DNA was obtained for genotyping from tail biopsies. Primers specific for the Vamp 8 wild-type allele (5'-CCGAAACAAGAC AGAGGACTTG-3' and 5'-CGTTAGGAATGGA 
GCAGTTGAC- $3^{\prime}$ ) and for the puro ${ }^{\mathrm{r}}$ cassette of the mutant allele (5'-CCGAGTACAAGCCCACGGTG-3' and 5'-CGCTGCCCAGACCCTTGCCC-3') were used for polymerase chain reaction (PCR) amplification and gave products of $290 \mathrm{bp}$ and $400 \mathrm{bp}$, respectively.

\section{Western blot analysis}

Freshly excised tissues were homogenized in TRIS-buffered saline (150 mM NaCl, $50 \mathrm{mM}$ TRIS-HCl pH 7.4) in an UltraTurrax homogenizer. The homogenates were supplemented with $0.1 \%$ Triton $\mathrm{X}-100$ and protease inhibitors $(1 \mathrm{mM}$ phenylmethylsulfonylfluoride, $0.5 \mu \mathrm{g} / \mathrm{ml}$ leupeptin, $1.0 \mu \mathrm{g} / \mathrm{ml}$ pepstatin). Total protein $(30 \mu \mathrm{g})$ was resolved by sodium dodecyl sulfate-polyacrylamide gel electrophoresis (SDS-PAGE) and transferred to nitrocellulose membranes (PROTRAN, Schleicher and Schuell, Germany). Polyclonal antibodies directed against vtila, vtilb (Antonin et al. 2000b), SNAP29, syntaxin 7, syntaxin 8 (Antonin et al. 2000a; Kreykenbohm et al. 2002), and VAMP8 (Synaptic Systems, Göttingen, Germany) were used for detection, and the bands were visualized by enhanced chemiluminescence (Pierce, Rockford, USA). For the detection of VAMP8, $1 \mathrm{mg}$ Triton$\mathrm{X}-100$-free homogenate was subjected to Triton X-114 extraction to enrich membrane proteins (Bordier 1981). The detergent fraction was concentrated by acetone precipitation.

\section{Histology}

Tissue samples were fixed in 4\% formaldehyde and embedded in paraffin. Thick sections $(5-10 \mu \mathrm{M})$ were obtained, deparaffinized, and stained with hematoxylin and eosin (HE). TUNEL (terminal deoxnucleotidyl transferase dUTP nick end labeling) staining to visualize the DNA breaks in apoptotic cells was performed with deparaffinized sections according to manufacturer's instructions (Dead EndTM Fluorometric TUNEL System; Promega Corporation, Madison, Wis., USA; Fayyazi et al. 2000). For immunohistology, deparaffinized sections were renaturated by microwaving for $20 \mathrm{~min}$ in $0.1 \mathrm{M}$ citrate buffer $(\mathrm{pH} \mathrm{6)}$ ) and incubated with rabbit anti-keratin 5 (Covance Research, Richmond, Calif., USA; 1:1000) and anti-keratin 8 (TROMA-1, Developmental Studies Hybridoma Bank, Iowa City, Iowa, USA; 1:30) antibodies overnight at $4^{\circ} \mathrm{C}$. Primary antibodies were detected with anti-rat Alexa 488 (Invitrogen, 1:300) and anti-rabbit Cy3 (Jackson Immunoresearch Laboratories, West Grove, Pa., USA; 1:200) secondary antibodies. Sections were examined by using a Leica DM5000.

\section{Single cell preparations}

Thymi of the mice were dissected, and adjacent lymph nodes were carefully removed when necessary. Single cell suspensions were prepared in Roswell Park Memorial Institute (RPMI) 1640 medium supplemented with $10 \%$ fetal calf serum (FCS), $2 \mathrm{mM}$ L-glutamine, and antibiotics (100 U/ml penicillin, $100 \mu \mathrm{g} / \mathrm{ml}$ streptomycin) by using a Tenbroek homogenizer, and cell numbers were determined in a Neubauer counting chamber. Single cell suspensions from other lymphoid organs were obtained similarly. Erythrocytes were removed from blood samples and spleen cell preparations by incubation for $5 \mathrm{~min}$ in erythrocyte lysis buffer $\left(155 \mathrm{mM} \mathrm{NH} 4 \mathrm{Cl}, 10 \mathrm{mM} \mathrm{KHCO}_{3}, 0.1 \mathrm{mM}\right.$ EDTA, pH 7.4-7.8).

\section{Flow cytometry}

Usually, $1 \times 10^{6}$ cells per measurement were washed in $5-\mathrm{ml}$ polystyrene tubes with phosphate-buffered saline (PBS) and resuspended in $100 \mu \mathrm{l}$ PBS before cell surface staining with $1 \mu \mathrm{g}$ of the respective antibodies: anti-CD3 (clone CT-CD3, rat IgG2a, phycoerythrin [PE]-labeled; Caltag Laboratories, Hamburg, Germany), anti-CD4 (clone CT-CD4, rat IgG2a, PE or tricolor [TC]-labeled; Caltag), anti-CD8a (clone CT-CD8a, rat IgG2a, fluorescein isothiocyanate [FITC] or PE-labeled), anti-CD8b (clone CT-CD8b, rat IgG2a, PElabeled; Caltag), anti-CD19 (clone 6D5, rat IgG2a, FIT C-labeled; Caltag), anti-CD25 (clone 7D4, rat IgM, FITClabeled, Becton Dickinson), anti-CD44 (clone IM7.8.1, rat IgG2b, biotin-labeled; Caltag), anti-CD45R/B220 (clone RA3-6B2, rat IgG2a, PE-labeled; Caltag), anti-mouse NK cells (clone DX5, rat IgM, PE-labeled; Caltag), anti-mouse NK1.1 (clone PK136, mouse IgG2a, PE-labeled; Caltag), anti-Ly-6G (clone RB6-8C5, rat IgG2b, PE-labeled; Caltag), anti-mouse erythroid cells (clone TER-119, rat IgG2b, PE-labeled; Caltag), anti-TCR $\alpha \beta$ (clone H57-597, hamster IgG, FITC-labeled; Caltag), or anti-I-A ${ }^{\mathrm{b}}$ (clone 25-5-16S, mouse IgM, FITC-conjugated). TC-conjugated streptavidin (SA1006, Caltag) was used as the secondary reagent. Appropriate isotype controls were purchased from Caltag Laboratories. The cells were stained for $45 \mathrm{~min}$ at $4^{\circ} \mathrm{C}$ before being washed and resuspended in $200 \mu \mathrm{l}$ PBS. Exposure of phosphatidylserine as a membrane parameter of apoptosis was determined by staining cells for $45 \mathrm{~min}$ at $4^{\circ} \mathrm{C}$ in binding buffer (10 mM HEPES/NaOH, $\mathrm{pH} 7.4$, $140 \mathrm{mM} \mathrm{NaCl}, 2.5 \mathrm{mM} \mathrm{CaCl}_{2}$ ) with $5 \mu \mathrm{l}$ annexin V-FITC (Becton Dickinson) in combination with $1 \mu \mathrm{g} / \mathrm{ml}$ propidium iodide (Sigma) to distinguish early apoptotic from late apoptotic or necrotic cells. The cells were resuspended in $200 \mu \mathrm{l}$ annexin binding buffer before measurement. DNA histograms were obtained after propidium iodide staining of cells fixed in ethanol as described previously (Ormerod et al. 1992; Dressel et al. 2000). Flow cytometry was performed on a FACScan flow cytometer with CellQuest software (Becton Dickinson, Heidelberg, Germany); 10,000 to 50,000 cells per sample were counted. Lymphocytes 
were gated on the basis of their forward scatter/side scatter characteristics.

Dexamethasone and FAS-induced apoptosis

Thymocytes $\left(1 \times 10^{6}\right)$ were transferred to two 5 -ml polystyrene tubes for each time point. Cells in the first tube were resuspended in $200 \mu \mathrm{l} 0.1 \mu \mathrm{M}$ dexamethasone (Sigma Taufkirchen, Germany) diluted in RPMI-1640 medium. In the second control tube, $200 \mu \mathrm{l}$ RPMI-1640 supplemented medium was added. The cells were incubated at $37^{\circ} \mathrm{C}$ for 0 , 3 , and $6 \mathrm{~h}$. For induction of apoptosis with an agonistic antiFAS antibody (clone Jo2, Becton Dickinson), $2 \times 10^{6}$ cells were resuspended in $200 \mu \mathrm{l}$ supplemented RPMI-1640 medium and exposed to $1 \mu \mathrm{g}$ of the antibody for 0,3 , and $6 \mathrm{~h}$ at $37^{\circ} \mathrm{C}$. The cells in the control tubes were incubated with $200 \mu$ of the supplemented medium only. After each time point, the cells were washed once with binding buffer and stained with annexin V-FITC and propidium iodide. The cells were finally resuspended in $200 \mu \mathrm{l}$ of the binding buffer before flow cytometry was performed. The number of viable cells was compared in the treated and untreated samples for each time point. In parallel, cells were fixed in ice-cold ethanol in order to determine apoptotic cells by subG1 peak analysis in DNA histograms.

Anti-CD3 and anti-CD28 antibody-mediated apoptosis

The assay was carried out as described elsewhere (Thien et al. 2005) in 96-well ELISA plates (F96 Maxisorp, Nunc, Roskilde, Denmark) that had been coated with $10 \mu \mathrm{g} / \mathrm{ml}$ anti-CD3 (clone 2C11, Becton Dickinson) and anti-CD28 (clone 37.51, Becton Dickinson) antibody mix, overnight at $4^{\circ} \mathrm{C}$. Thymocytes $\left(2 \times 10^{6}\right)$ were transferred to each of the wells and incubated for $0,3,6$, and $24 \mathrm{~h}$. For each time point, a control sample was incubated in an uncoated well with $100 \mu \mathrm{l}$ medium. The cells were collected in $5-\mathrm{ml}$ polystyrene tubes and washed with annexin $\mathrm{V}$ binding buffer before being stained with annexin V-FITC and propidium iodide.

\section{Reconstitution assays}

Bone marrow cell suspensions were isolated from small and sick $\operatorname{Vamp}^{-/-}$mice and healthy heterozygous littermates. The bone marrow cells $\left(1 \times 10^{6}\right)$ were intravenously injected into irradiated (9 Gy) $\operatorname{Rag}^{-/-} \gamma \mathrm{c}^{-/-}$mice; these mice are deficient for $\mathrm{T}$ and $\mathrm{B}$ lymphocytes and natural killer (NK) cells because of a knockout of the recombination activation gene 2 and the common $\gamma$ chain gene, which encodes a protein that is part of several cytokine receptors (Cao et al. 1995). At various time points after transplantation, peripheral blood was collected and analyzed by flow cytometry for reconstitution with $\mathrm{B}$ and $\mathrm{T}$ lymphocytes. From later sacrificed animals, thymi and spleens were also obtained and analyzed by flow cytometry.

\section{Statistics}

Differences between multiple experimental groups were analyzed by using the nonparametric Kruskal-Wallis test and WinSTAT software. Paired comparisons between two groups were performed by using the nonparametric MannWhitney U test. A significance level of $P=0.05$ was used. Adjustments for multiple comparisons were performed when appropriate with the Bonferroni-Holm procedure.

\section{Results}

VAMP8-deficient mice were obtained by a gene trap strategy

Lexicon Genetics (The Woodlands, USA) created a library of mutant mouse embryonic stem cells by using a gene trap strategy involving random insertional mutagenesis (Zambrowicz et al. 1998). The employed gene trap vector VICTR20 consisted of a splice acceptor site, followed by an internal ribosome entry site, a galactosidase/neomycin phosphotransferase fusion gene, and a polyadenylation signal yielding a first mRNA. The second part of VICTR2 0 contained a phosphoglycerate kinase-1 promoter, a puromycin $\mathrm{N}$-acetyltransferase gene, and a splice acceptor sequence generating a second mRNA, which was used to determine the point of insertion. Mice were generated from OST20346 by the Merck Genome Research Institute, and we obtained them from Jackson Laboratory (Bar Harbor, USA) as strain Vamp $8^{\text {tmlLex }}$.

The Vamp 8 gene encompasses four exons. Exon 1 encodes the $5^{\prime}$ untranslated region (UTR), exon 2 encodes the $5^{\prime}$ UTR and the first amino acid M1, exon 3 (nucleotides 2637-2796 in the mouse genomic DNA clone with GenBank accession number AF247556) encodes amino acids (aa) E2-T54, and exon 4 (nucleotides 54525727) encodes aa S55-T101 and the 3' UTR. The SNARE motif of VAMP8 is encoded in part by exon 3 (aa 13-54) and exon 4 (aa 55-62).

In order to localize the insertion cassette to a definite position, we performed several sets of PCRs with different forward and reverse primers. We pinpointed the site of the gene trap insertion in intron 3 following exon 3 between nucleotides +10 and +253 (data not shown). Vamp 8 mRNA was not detected by Northern blot in homozygote-null heart and muscle and was barely detected in kidney (Jackson Laboratory), despite the kidney being reported to have the highest levels of Vamp 8 mRNA (Advani et al. 1998). Both 
mRNAs encoded by the gene trap allele cannot encode functional proteins, because both mRNAs encode only part of the SNARE motif, which is essential for function.

SNARE expression profiling of VAMP8-deficient mice confirmed the loss of VAMP8 protein in the thymus

In order to confirm that the $\operatorname{Vamp} 8^{\text {tm1Lex }}$ mice did not contain significant amounts of VAMP8 protein, we determined the protein levels in $V a m p 8^{+/+}, \operatorname{Vamp}^{+/-}$, and $V a m p 8^{-/-}$mice by Western blot. We focused on thymus because this organ was abnormal in $\operatorname{Vamp}^{-/-}$mice (see below). VAMP8 was present in the thymus of $\operatorname{Vamp}^{+/+}$and $V a m p 8^{+/-}$mice but not in $V a m p 8^{-/-}$mice (Fig. 1). Thus, loss of VAMP8 could have functional consequences for the function of the thymus and the development of $\mathrm{T}$ lymphocytes. Our previous work indicated that syntaxin 8 is degraded in the absence of vtilb in $\mathrm{Vtilb}^{-/-}$mice (Atlashkin et al. 2003). Therefore, we wanted to know whether the expression levels of other SNARE proteins were changed because of the absence of VAMP8. Lack of VAMP8 did not significantly alter the amount of the VAMP8 complex partners syntaxin 8 or vtilb (Fig. 1). We also did not observe major changes in the amounts of syntaxin 7, the fourth member of the late endosomal SNARE complex (data not shown). The loss of the late endosomal SNARE complex could be compensated by other SNAREs. However, major changes in the amounts of SNAP29 or of the early endosomal SNARE vtila were not observed (Fig. 1).

\section{Vamp8+/+ Vamp8+/- Vamp8-/-}

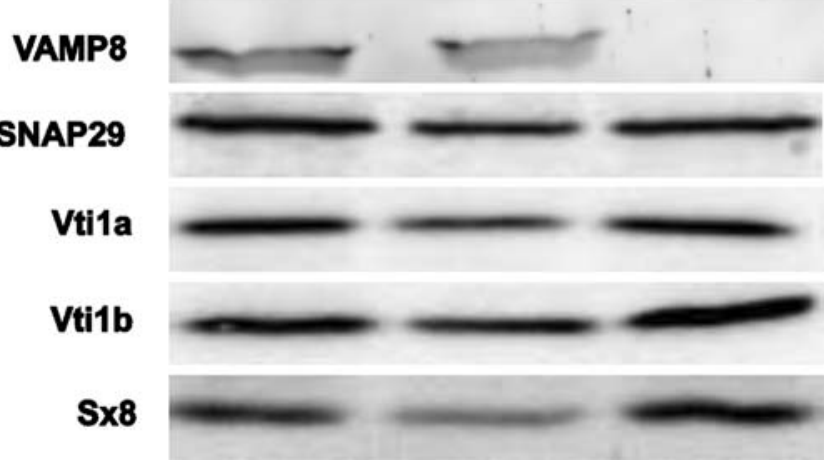

Fig. 1 SNARE protein VAMP8 was not expressed in the thymus of Vamp $8^{-1-}$ mice. A SNARE protein expression profile was determined in thymi from 1.5-month-old $\operatorname{Vamp}^{+/+}, \operatorname{Vamp}^{+/-}$, and $\operatorname{Vamp}^{-/-}$mice by immunoblot. For the detection of syntaxin 8 , SNAP29, vti1a, and vtilb, $30 \mu \mathrm{g}$ total protein derived from thymus homogenate was loaded in each lane. For the detection of VAMP8, $250 \mu \mathrm{g}$ total protein was subjected to Triton $\mathrm{X}-114$ extraction, and the precipitated membrane protein fraction was loaded onto the gel
Ablation of VAMP8 caused early mortality

Vamp $8^{-/-}$mice were born in the expected Mendelian ratio indicating normal prenatal development. However, 20 out of $55 \mathrm{Vamp}^{-/-}$mice died before reaching the age of 1 month. In comparison, only $2 \%$ ( 2 out of 88 ) of $\mathrm{Vtill}^{-/-}$ mice (Atlashkin et al. 2003) that we bred in parallel were lost during this time. Up to postnatal day 7, all $\operatorname{Vamp} 8^{-/}$ mice showed normal weight gain. After this time, $36 \%$ of the mice lost weight for 2-3 days and eventually died (Fig. 2a). One day after begin of weight loss, the mice were smaller than their heterozygous littermates, but they were active and apparently healthy. We described this stage as "small and healthy". After consecutive weight loss for 23 days, the mice appeared very weak, had a shivery gait, and on average weighed 1.8-fold less than their heterozygous littermates (Fig. 2b,c). This stage was described as "small and sick", and these mice eventually died. The weight-gain pattern of $\operatorname{Vamp~}^{+/-}$mice was indistinguishable from wild-type mice. The $\operatorname{Vamp} 8^{-/-}$mice that survived these early postnatal days became healthy fertile adults but remained smaller and lighter than their heterozygous littermates.

VAMP8-deficient mice showed disrupted thymus morphology

Liver, kidney, heart, brain, intestine, spinal cord, and thymus from small and sick $\operatorname{Vamp} 8^{-/-}$, healthy $\operatorname{Vamp} 8^{-/-}$ (1 month old), and wild-type mice were examined histologically. All organs from the small and sick Vamp $8^{-1-}$ mice were normal and similar to those of wildtype mice, except for the thymus and pancreas. Thymi from the small and sick $\operatorname{Vamp} 8^{-1-}$ mice were much smaller than the thymi from the $\operatorname{Vamp} 8^{+/-}$littermates (Fig. 2d). The thymus size of $\operatorname{Vamp}^{+/-}$mice was similar to that of wild-type mice (data not shown). Thymus sections from a 10-day-old wild-type mouse showed a well-defined compartmentalization into cortex and medulla (Fig. 3a). The thymus of the healthy adult $\operatorname{Vamp} 8^{-/-}$mouse appeared similar to the wild-type thymus with distinct cortical and medullary regions (Fig. 3b). In contrast, thymi from small and sick $\operatorname{Vamp}^{-/-}$mice did not show a morphological distinction into medulla and cortex (Fig. 3c). The thymi of $\operatorname{Vamp~}^{-/-}$and $\operatorname{Vamp} 8^{+/-}$mice at day 7 before animals started to loose weight were histologically similar (data not shown). To determine further the basis of the missing compartmentalization of the thymus in $\operatorname{Vamp} 8^{-/-}$mice, we analyzed the thymus epithelium in small and sick and in small and healthy Vamp $8^{-1-}$ mice by immunofluorescence microscopy. Cortex and medulla contain different thymic epithelial cells (TEC), which are crucial components of the various thymic microenvironments and guide $\mathrm{T}$ cell development (Takahama 


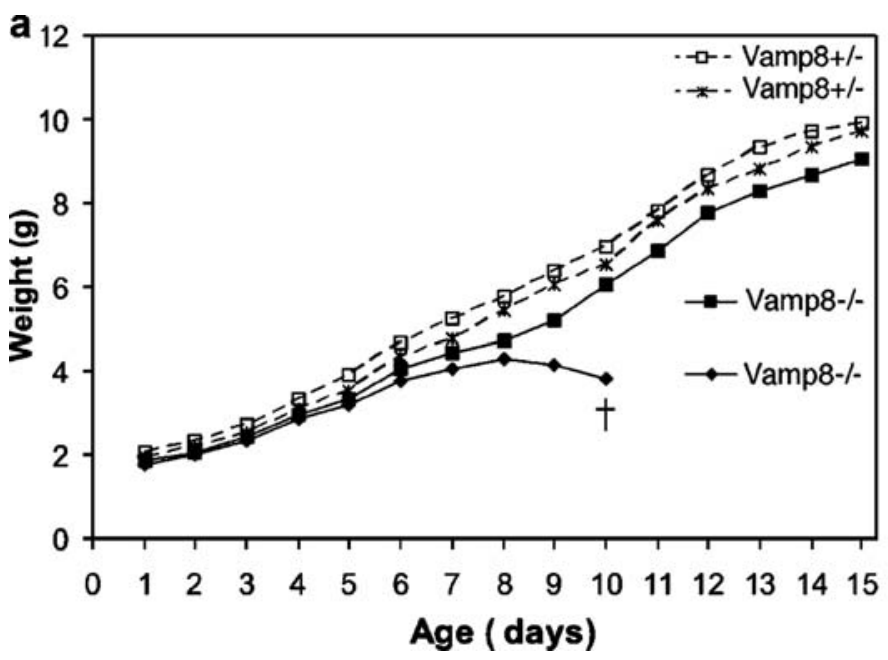

Fig. 2 Growth pattern of $V a m p 8^{-/-}$mice revealed a heterogeneous phenotype. a Weight-gain pattern of a representative litter illustrates heterogeneity in the phenotype of VAMP8-deficient mice. One Vamp $8^{-1-}$ pup lost weight starting at postnatal day 9, became sick, and eventually died. The other $\operatorname{Vamp} 8^{-/}$pup survived and gained weight as did the $\operatorname{Vamp} 8^{+/-}$pups. b A summary of the mean weights $( \pm \mathrm{SD})$ of sick 8- to 12-day-old $\operatorname{Vamp}^{-/-}$mice that died and their heterozygous littermates is shown. The weight of $\operatorname{Vamp} 8^{-/-}$mice was,

2006). Medullary thymic epithelial cells (mTEC) were identified by the presence of keratin 5 , and cortical thymic epithelial cells (cTEC) by keratin 8 expression (Franke et al. 1981; Klug et al. 1998). Both keratin-5-positive and keratin8-positive cells were present in thymi from small and sick Vamp $8^{-/-}$mice (data not shown) and in small and healthy Vamp $8^{-/-}$mice (Fig. 4a-b"). However, the normally strict boundary between cTEC and mTEC was ill-defined, even in the small and healthy $\operatorname{Vamp}^{-/-}$mice, as compared with that of their $\operatorname{Vamp}^{+/-}$littermates (Fig. 4c-d") and wild-type mice (Fig. 4e-f"). Both epithelial cell types were mixed and severely disordered. These data indicated that absence of VAMP8 resulted in a disorganization of thymus epithelium even in small and healthy $\operatorname{Vamp} 8^{-/-}$mice several days before the onset of the most dramatic phenotypes (see below). In addition, we observed a histological defect in the pancreas of
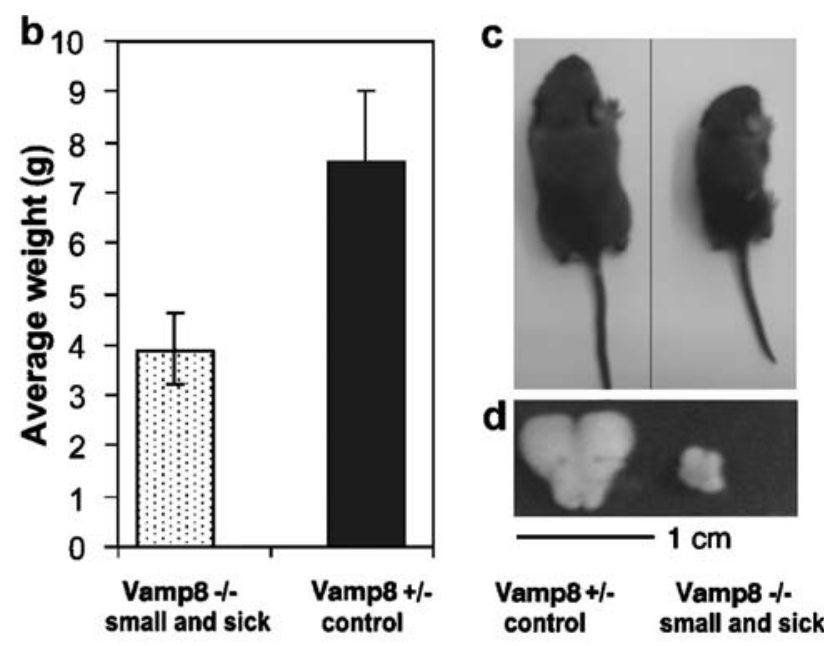

on average, $3.9 \pm 0.7 \mathrm{~g}$ compared with $7.6 \pm 1.4 \mathrm{~g}$ for $\mathrm{Vamp}^{+/-}$ littermates $(n=7, P=0.0016$, U test). $\mathbf{c}$ Representative photograph of a small and sick $\operatorname{Vamp}^{-/-}$mouse and a heterozygous littermate illustrating the differences in size and weight of these animals. d The size of the thymus of the $\operatorname{Vamp} 8^{-/-}$mouse was disproportionally smaller than that of its herterozygous littermate (representative photograph)

all Vamp $8^{-/-}$mice (data not shown). These mice had an abnormally large and creamy pancreas as described previously for a different line of $\operatorname{Vamp~}^{-/-}$mice (Wang et al. 2004).

Vamp $8^{-/-}$mice showed a reduction in thymus cellularity and the thymocyte subsets were altered

The numbers of thymocytes were significantly reduced in small $\operatorname{Vamp~}^{-/-}$mice (Table 1). The small and sick stage was the most severely affected and showed a 10-fold reduction in thymocyte counts compared with their heterozygous littermates. Interestingly, the total cell count in the thymi of small and healthy $\operatorname{Vamp} 8^{-1-}$ mice was also reduced and about half of the $\operatorname{Vamp~}^{+/-}$control littermates. In contrast, no significant reduction was seen in the thymus cell count in healthy $\operatorname{Vamp} 8^{-/-}$at day 7 before the deleterious phenotype occurred
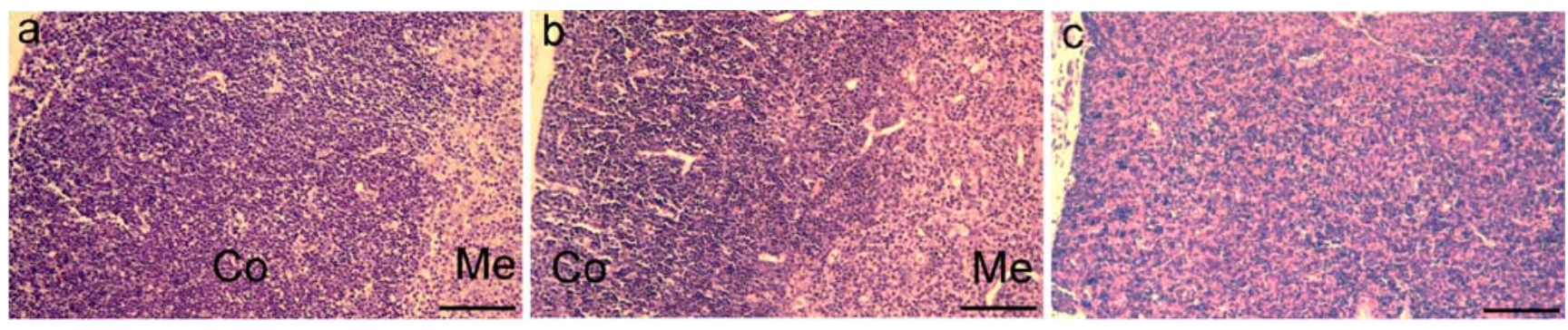

Fig. 3 VAMP8 deficiency leads to histopathological alterations of the thymus. Hematoxylin and eosin staining of sections from the thymus of a 10-day-old wild-type mouse (a) and a healthy adult $\operatorname{Vamp} 8^{-/-}$ mouse (30 days old, b) showing two compartments: cortex $(\mathrm{Co})$ and medulla $(\mathrm{Me})$. The thymus of a small and sick $\operatorname{Vamp}^{-/-}$mouse
(11 days old, c) did not show the characteristic compartmentalization into cortex and medulla. Medullary cells (pink) were scattered throughout the thymic cortex (blue). Micrographs taken at $\times 100$ magnification, bars $100 \mu \mathrm{m}$ 
or in healthy adult mice (Table 1). We wanted to know at which stage VAMP8 deficiency affected the development of thymocytes in the small and sick $\operatorname{Vamp} 8^{-/}$mice. The switching from $\mathrm{CD} 4^{-} \mathrm{CD} 8^{-} \mathrm{DN}$ precursors to $\mathrm{CD} 4^{+} \mathrm{CD} 8^{+}$ $\mathrm{DP}$ and eventually to mature $\mathrm{CD}^{+}$or $\mathrm{CD}^{+} \mathrm{SP} \mathrm{T}$ lymphocytes defines major steps in the development of thymocytes. Therefore, we analyzed these markers on thymocytes from small and sick, small and healthy, healthy 7-day-old, and healthy adult $\operatorname{Vamp} 8^{-/-}$mice and on thymocytes of heterozygous littermates by flow cytometry (Fig. 5a). The percentage of $\mathrm{CD}^{+} \mathrm{CD}^{+}$DP cells was significantly reduced (on average 1.6-fold) in small and sick Vamp $8^{-/}$mice, whereas the percentage of $\mathrm{CD}^{+} \mathrm{SP}$ was significantly increased (on average 4.3 -fold). The proportion of the other thymocyte populations showed a tendency to increase $\left(\mathrm{CD}^{+} \mathrm{SP}\right.$ on average 3.2 -fold and $\mathrm{CD} 4^{-} \mathrm{CD} 8^{-} \mathrm{DN}$ on average 2.5 -fold); however, this was not statistically significant after correction for multiple testing (Fig. 5b). Of note, although the proportion of DN and SP thymocytes appeared to increase in the thymi of small and sick $\operatorname{Vamp} 8^{-/-}$ mice, the absolute number of all four cell populations significantly decreased (Fig. 5b). The Vamp $8^{-/-}$mice had only $9 \%$ of the DP cell numbers found in the heterozygous littermates. For the DN cells, this proportion was $20 \%$, for $\mathrm{CD}^{+} \mathrm{SP}$ cells $25 \%$, and for $\mathrm{CD} 4^{+} \mathrm{SP}$ cells $36 \%$. There was no difference in the CD4/CD8 subsets in thymi of small and healthy $\operatorname{Vamp}^{-/-}$mice (Fig. 5c), in $\operatorname{Vamp} 8^{-/-}$mice at day 7 before a fraction of mice became sick (data not shown), or in adult $\operatorname{Vamp~}^{-/-}$mice (data not shown) compared with the respective controls.

The $\mathrm{T}$ cell receptor (TCR) is a key molecule, which must be expressed by DP thymocytes to have a chance for successful positive selection and by CD4 SP and CD8 SP cells for proper $\mathrm{T}$ cell function. Thymocytes with a TCR that cannot interact with self-MHC molecules die by neglect (Kisielow et al. 1988). The most prominent reduction of the DP population prompted us to study the expression of the TCR $\alpha \beta$ in the Vamp $8^{-/-}$ mice. A flow cytometric analysis showed an increase in the percentage of $\mathrm{TCR}^{\text {high }}$ cells in small and sick $\operatorname{Vamp}^{-/-}$mice (Fig. 5d). This can been explained by the massive increase in the proportion of $\mathrm{CD}^{+}$and $\mathrm{CD} 8^{+} \mathrm{SP}$ cells in the thymi of these mice. The TCR expression level on the TCR ${ }^{\text {low }}$ and $\mathrm{TCR}^{\text {high }}$ cell populations was not markedly different between the genotypes. Similarly, the proportion of $\mathrm{CD}^{+}$cells was increased in thymi of $\mathrm{Vamp}^{-/-}$mice (data not shown).

$\mathrm{CD} 4^{-} \mathrm{CD} 8^{-} \mathrm{DN}$ thymocytes subsets were disturbed in small and sick $\operatorname{Vamp} 8^{-/-}$mice

Since the absolute numbers of DN thymocytes were also reduced, a block in their development might have been responsible for the prominent reduction of DP thymocytes in the small and sick $\operatorname{Vamp} 8^{-/-}$mice. Therefore, we performed an analysis of the DN subsets. The DN thymocytes are subdivided into four developmental stages depending on the sequential expression of surface molecules CD44 and CD25: DN1 $\left(\mathrm{CD} 44^{+} \mathrm{CD} 25^{-}\right)$, DN2 $\left(\mathrm{CD} 44^{+} \mathrm{CD} 25^{+}\right)$, DN3 $\left(\mathrm{CD} 44^{-} \mathrm{CD} 25^{+}\right)$, and $\mathrm{DN} 4$ (CD44 $4^{-} \mathrm{CD} 25^{-}$; Godfrey et al. 1993). In order to confine the analysis to the $\mathrm{CD} 4^{-} \mathrm{CD} 8^{-} \mathrm{T}$ lymphocyte progenitor cells, we gated on the lymphocyte population in forward/ sideward scatter plots and on cells that were negative for $\mathrm{T}$ cell (CD4, CD8, and CD3), B cell (B220), NK cell (NK1.1, and DX5), erythrocyte (TER-119), and granulocyte (Ly6G) markers. Although we could detect all DN subpopulations (DN1-DN4) in the thymus from small and sick $\operatorname{Vamp}^{-/-}$mice, the percentage of these subsets was different from the controls (Fig. 6). The percentage of DN1 cells $\left(\mathrm{CD} 44^{+} \mathrm{CD} 25^{-}\right.$, Fig. 6a) increased significantly (on an average six-fold), whereas the DN2 $\left(\mathrm{CD} 44^{+} \mathrm{CD} 25^{+}\right.$, Fig. 6b) and DN3 (CD44- CD25 $5^{+}$, Fig. 6c) cells were significantly (three-fold and 2.5-fold) reduced, respectively ( $P<0.05$, U test, corrected for multiple testing). The DN4 (CD44 ${ }^{-} \mathrm{CD} 25^{-}$, Fig. $6 \mathrm{~d}$ ) population showed a tendency to increase (on average two-folds). Thus, the subpopulations within the DN compartment were also disturbed in small and sick $\operatorname{Vamp} 8^{-/-}$mice. The transition from DN1 to DN2 appeared to be most severely affected. In contrast, the small and healthy $\operatorname{Vamp} 8^{-/-}$and adult $\operatorname{Vamp} 8^{-/-}$mice showed no disturbance in the DN subpopulations (data not shown).

Proliferation of thymocytes in small and sick and in small and healthy $\operatorname{Vamp} 8^{-/-}$mice was reduced

Thymocytes undergo several cycles of vigorous proliferation at defined developmental stages. To determine the proportion of proliferating cells in the thymus, we performed flow cytometric cell cycle analyses of propidium-iodide-stained ethanol-fixed cells (Fig. 7a). The proportion of proliferating cells in the S and G2 phases in small and sick $\operatorname{Vamp} 8^{-/-}$mice was significantly reduced compared with that in heterozygous littermates (Fig. 7b). In addition, the percentage of apoptotic cells appearing in the subG1 region of DNA histograms was increased. Interestingly, a reduced proliferation of thymocytes was also observed in small and healthy $\operatorname{Vamp} 8^{-/-}$mice $(P=0.014$, $\mathrm{U}$ test), but the proportion of apoptotic cells was not increased (Fig. 7c). In adult $V a m p 8^{-/-}$mice, the percentage of proliferating cells was not altered compared with that in heterozygous controls (data not shown).

Small and sick $\operatorname{Vamp} 8^{---}$mice showed an increased number of apoptotic cells in the thymus

Thymocytes are subjected to stringent check points during their development. Those cells that do not pass through 
these checkpoints successfully are subjected to apoptotic cell death. The results of the cell cycle analysis, the observed disruption in thymus morphology, and the developmental defect of the thymocytes prompted us to study the extent of cell death in the thymi of $\operatorname{Vamp} 8^{-/-}$mice in more detail. Thymi from small and sick $\operatorname{Vamp} 8^{-1-}$ mice (Fig. 8a) contained increased numbers of apoptotic cells compared with controls as shown by TUNEL staining in representative tissue sections (Fig. 8b). By contrast, the normal low levels of apoptotic cells were detected in thymus sections of small and healthy $\operatorname{Vamp~}^{-/-}$mice (Fig. 8c), despite the disorganization of cTEC and mTEC detectable in these mice (see Fig. 4a,b). Ex vivo doublestaining of thymocytes from small and sick $\operatorname{Vamp} 8^{-/-}$mice with annexin $\mathrm{V}$ and propidium iodide revealed an average of $41 \%$ live cells compared with $85 \%$ in the $\operatorname{Vamp} 8^{+-}$ controls ( $\mathrm{P}=0.0209$, $\mathrm{U}$ test, Fig. 8d). The increased proportion of dead thymocytes was found predominantly among the DP cells in $\operatorname{Vamp~}^{-/-}$mice when annexin $\mathrm{V}$ was combined with CD4 and CD8 staining (Fig. 8e). On the other hand, the thymi of small and healthy $\operatorname{Vamp} 8^{-/}$and healthy adult $\operatorname{Vamp} 8^{-/-}$mice did not contain increased numbers of dead cells (Fig. 8d).

Isolated thymocytes from small and healthy $\operatorname{Vamp}^{-/-}$mice were more susceptible to apoptosis induced in vitro

We reasoned that the reduced number of thymocytes in Vamp $8^{-/-}$mice might be attributable to an increased sensitivity of the cells toward apoptosis. Therefore, we studied the susceptibility of thymocytes from small and sick, from small and healthy, and from healthy adult Vamp $8^{-/-}$mice to several apoptotic stimuli. First, cell death was induced in isolated thymocytes with $0.1 \mu \mathrm{M}$ dexamethasone. Ethanol-fixed cells were incubated with propidium iodide to determine DNA content. The number of cells appearing in the subG1 region of the DNA histograms was determined. Alternatively, the cells were stained with annexin $\mathrm{V}$ and propidium iodide. The number of viable cells was evaluated at various time points after treatment. More apoptosis was induced in thymocytes of small and healthy $\operatorname{Vamp} 8^{-/-}$mice at $3 \mathrm{~h}$ and $6 \mathrm{~h}$ after exposure to dexamethasone compared with $\operatorname{Vamp} 8^{+/-}$controls, as determined in DNA histograms (Fig. 9a) and by annexin $\mathrm{V}$ and propidium iodide staining (data not shown). This indicated that the isolated thymocytes from the small and healthy mice were more sensitive to cell death upon dexamethasone treatment. The thymocytes from small and sick $\operatorname{Vamp} 8^{-/-}$mice contained much fewer viable cells (on average $40 \%$ ), even before dexamethasone treatment, and little additional apoptosis could be induced in these cells (data not shown). In adult $\operatorname{Vamp} 8^{-/-}$thymocytes, the rate of apoptosis induced by dexamethasone was not increased
Fig. 4 VAMP8 deficiency leads to altered distribution of cortical thymic epithelial cells (cTEC) and medullary thymic epithelial cells (mTEC). mTEC were identified by keratin 5 (red) and cTEC by keratin 8 (green) immunostaining. Both cell populations were present in a small and healthy $\operatorname{Vamp} 8^{-/-}$mouse (8 days old, a-b"). However, their distribution was scattered and disorganized in comparison with a Vamp $8^{+/-}$control littermate (c-d") and a wild-type mouse (8 days old, e-f"). Fluorescence micrographs taken at a magnification of $\times 100$, bars $50 \mu \mathrm{m}(\mathbf{a}, \mathbf{c}, \mathbf{e})$; enlargements of boxed areas taken at $\times 400$, bars $10 \mu \mathrm{m}(\mathbf{b}, \mathbf{d}, \mathbf{f})$

compared with $\operatorname{Vamp} 8^{+/-}$thymocytes (data not shown). Next, cell death was induced in isolated thymocytes from small and healthy $\operatorname{Vamp}^{-1-}$ mice by stimulation with antiCD3 and anti-CD28 antibodies. The percentage of cells in which apoptosis was induced was calculated by subtracting the percentage of viable cells in treated samples from that in untreated samples at each time point. The thymocytes from small and healthy $\operatorname{Vamp}^{-1-}$ mice had a two-fold increased susceptibility to apoptosis when measured after $24 \mathrm{~h}$ (average $42 \%$ apoptosis induction) compared with the controls (average 21\% apoptosis induction, Fig. 9b). Furthermore, thymocytes from small and healthy $\operatorname{Vamp} 8^{-/-}$mice showed an increased induction of apoptosis at $6 \mathrm{~h}$ after treatment with an apoptosis-inducing anti-FAS antibody compared with thymocytes from $\operatorname{Vamp~}^{+/-}$littermates (Fig. 9c). These results indicated that the thymocytes from small and healthy $\operatorname{Vamp} 8^{-/-}$mice were more susceptible to apoptotic stimuli than those from their heterozygous littermates. Thus, an increased sensitivity to apoptosis could have contributed to the observed decrease in the total thymus cellularity observed in these mice.

Hematopoetic stem cells from small and sick Vamp $8^{-/-}$ mice are not defective and give rise to $\mathrm{T}$ lymphocytes in $\operatorname{Rag} 2^{-/-} \gamma \mathrm{c}^{-/-}$mice

The number of thymocytes in small and healthy $\operatorname{Vamp} 8^{-/-}$ mice was found to be reduced, their proliferation was impaired, and their sensitivity to apoptosis was augmented in vitro despite a still normal distribution of thymocytes subsets and a normal rate of apoptotic thymocytes in vivo. Importantly, the organization of epithelial cells was also found to be disturbed even in the small and healthy Vamp $8^{-/-}$ mice. Therefore, whether the VAMP8 deficiency in the stroma impaired $\mathrm{T}$ cell development or the VAMP8 deficiency in the thymocytes disturbed the organization of the stroma was unclear. To address this question, we transplanted bone marrow derived from five small and sick $\operatorname{Vamp~}^{-/-}$and five healthy $\operatorname{Vamp} 8^{+/-}$littermates into Rag2 ${ }^{-1-} \gamma c^{-1-}$ mice, which lack $\mathrm{T}$ and $\mathrm{B}$ lymphocytes (Fig. 10a,d,g) and natural killer cells but contain thymus stromal cells (Cao et al. 1995). Bone marrow cells $\left(1 \times 10^{6}\right)$ were intravenously injected into $\mathrm{Rag} 2^{-/-} \gamma \mathrm{c}^{-/-}$mice that had been previously irradiated in order to open stem cell niches 


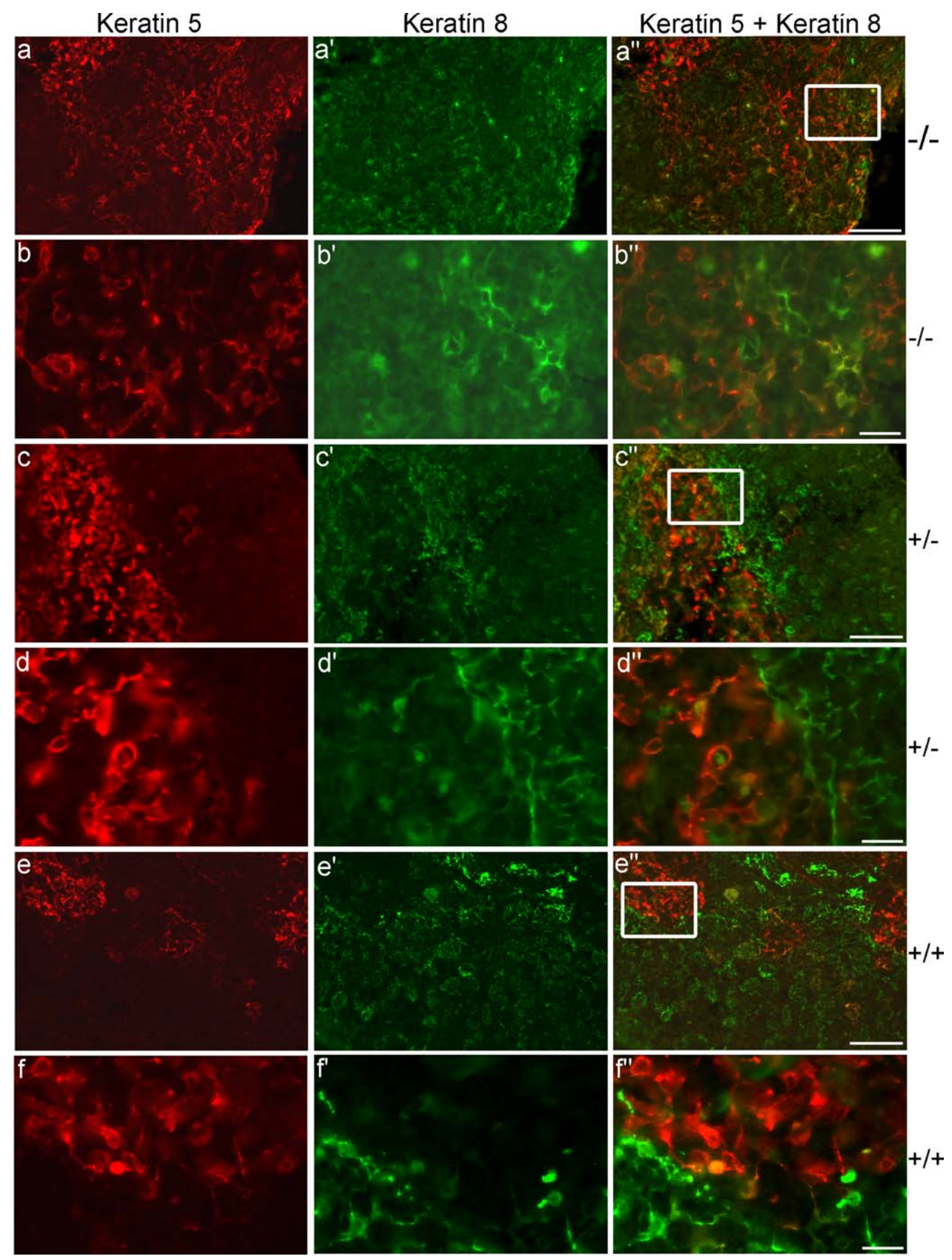


Table 1 Total thymocyte numbers in various groups of $\operatorname{Vamp} 8^{-/-}$mice compared with controls

\begin{tabular}{|c|c|c|c|c|c|c|c|}
\hline Genotype & Phenotype & Age & Number & $\begin{array}{l}\text { Cell count in } \\
\text { knockouts }^{\mathrm{a}}\end{array}$ & $\begin{array}{l}\text { Cell count } \\
\text { controls }^{\mathrm{a}, \mathrm{b}}\end{array}$ & $\begin{array}{l}\text { Fold decrease in } \\
\text { knockout }\end{array}$ & $\begin{array}{l}P- \\
\text { value }^{\mathrm{c}}\end{array}$ \\
\hline Vamp $8^{-1-}$ & Healthy & 7 days & 5 & $39 \pm 4$ & $44 \pm 13$ & 1.1 & 0.1761 \\
\hline Vamp $8^{-/-}$ & Small and sick & 8 to 12 days & 7 & $26 \pm 14$ & $261 \pm 13$ & 10.0 & 0.0017 \\
\hline Vamp $8^{-/-}$ & Small and healthy & 8 to 12 days & 4 & $140 \pm 32$ & $265 \pm 24$ & 1.9 & 0.0209 \\
\hline Vamp $8^{-/-}$ & Healthy & $\begin{array}{l}1 \text { to } \\
1.5 \text { months }\end{array}$ & 4 & $170 \pm 14$ & $241 \pm 62$ & 1.4 & 0.1489 \\
\hline
\end{tabular}

$\mathrm{a} \times 10^{6}$

${ }^{\mathrm{b}}$ Vamp $8^{+/-}$littermates were used as controls for $V a m p 8^{-/-}$mice. The same number of control and knockout mice was used to determine thymocyte numbers

${ }^{\mathrm{c}} P$-values were calculated by using the $\mathrm{U}$ test

efficiently in the host bone marrow. The development of $\mathrm{T}$ and B lymphocytes was followed by analysis of the blood from the transplanted mice over a period of up to 23 weeks. After 4 weeks, the transplanted bone marrow gave rise to CD19 and B220-positive B lymphocytes in all mice (Fig. 10h,i, with data after 7 weeks). After 6-7 weeks, $\mathrm{CD}^{+} \mathrm{CD}^{+}$(Fig. 10b,c) and $\mathrm{CD}^{+} \mathrm{CD}^{+} \mathrm{T}$ lymphocytes (Fig. 10e,f) were found in the blood of all transplanted mice. After 14, 16, and 23 weeks, pairs of animals transplanted with bone marrow from small and sick $\operatorname{Vamp} 8^{-1-}$ or healthy
Vamp $8^{+/-}$littermates were sacrificed. In the thymi, between $60 \%$ and $79 \% \mathrm{CD}^{+} \mathrm{CD} 8^{+} \mathrm{DP}$ lymphocytes were found indicating an efficient repopulation by progenitor cells from small and sick $\operatorname{Vamp}^{-/-}$mice similar to that from Vamp $8^{+/-}$ littermates. The spleens of these animals contained between $10 \%$ and $24 \% \mathrm{CD}^{+} \mathrm{CD}^{+}$cytotoxic $\mathrm{T}$ lymphocytes and between $17 \%$ and $24 \% \mathrm{CD}^{+} \mathrm{CD}^{+} \mathrm{T}$ helper lymphocytes. In addition, the number of thymocytes and splenocytes was in a similar range in mice receiving bone marrow from $V a m p 8^{-/-}$ mice or from $\operatorname{Vamp}^{+-}$littermates (data not shown). Thus,

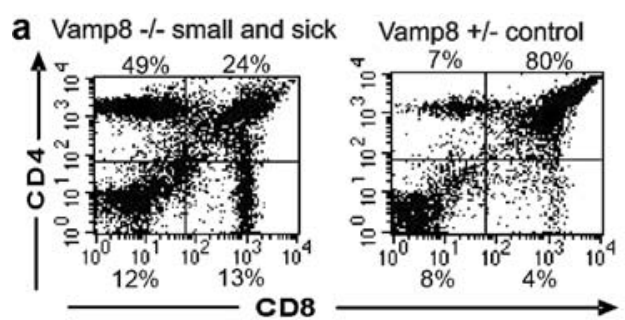

C

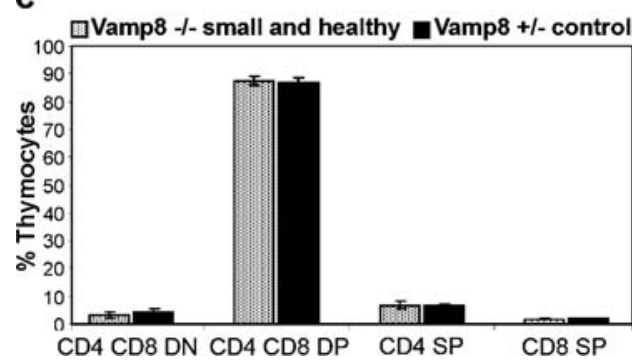

Fig. 5 Proportion of $\mathrm{CD} 4^{+} \mathrm{CD} 8^{+} \mathrm{DP}$ thymocytes was decreased in small and sick $\mathrm{Vamp}^{-/-}$mice. a Representative flow cytometric analysis of thymocytes from a 10-day-old small and sick Vamp $8^{-/-}$ mouse showing the presence of the four major subpopulations defined by CD4 and CD 8 markers. The proportion of DP cells was drastically reduced compared with that of a heterozygous littermate. b Summary of the proportion of CD4/CD8 subsets obtained from small and sick Vamp $8^{-/-}$mice and heterozygous littermates (bars percentage of thymocytes subpopulations $\pm \mathrm{SD} ; n=5$, age: $9-12$ days, $* P<0.05, \mathrm{U}$ test, corrected for multiple testing). The absolute cell number of CD4/ CD8 subsets in 9- to 13-day-old small and sick $\operatorname{Vamp}^{-/-}$mice and heterozygous littermates is given below $(P=0.0039$, $\mathrm{U}$ test, for the comparisons of $\operatorname{Vamp}^{-/-}$and $\operatorname{Vamp} 8^{+/-}$mice). c Small and healthy

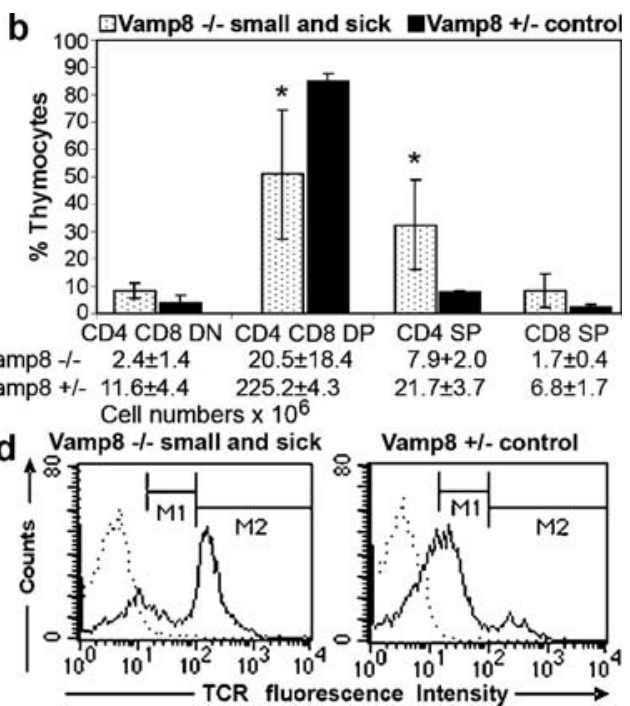

Vamp $8^{-/-}$mice did not show alterations of thymocytes subsets compared with heterozygous littermates $(n=3$, age: 9-12 days). d Representative histogram of T cell receptor- $\alpha \beta$ (TCR $\alpha \beta)$ staining of thymocytes from a small and sick $\operatorname{Vamp} 8^{-/-}$mouse and a heterozygous littermate (dotted line cells stained with the isotype control, solid line staining with an anti-TCR antibody). As seen left, the percentage of cells expressing the TCR at high intensity was increased in the small and sick $\operatorname{Vamp}^{-/-}$mice compared with the heterozygous littermate (right). However, the intensity of fluorescence was in the same range for the $\mathrm{TCR}^{\text {high }}$ (marker M2: mean fluorescence intensity 232 for Vamp $8^{-/-}$and 258 for $\operatorname{Vamp~}^{+/-}$) and the TCR ${ }^{\text {low }}$ (marker M1: mean fluorescence intensity 45 for $V a m p 8^{-/-}$and 39 for $V a m p 8^{+/-}$) cells in the small and sick Vamp $8^{-/-}$mice and in the control mice 

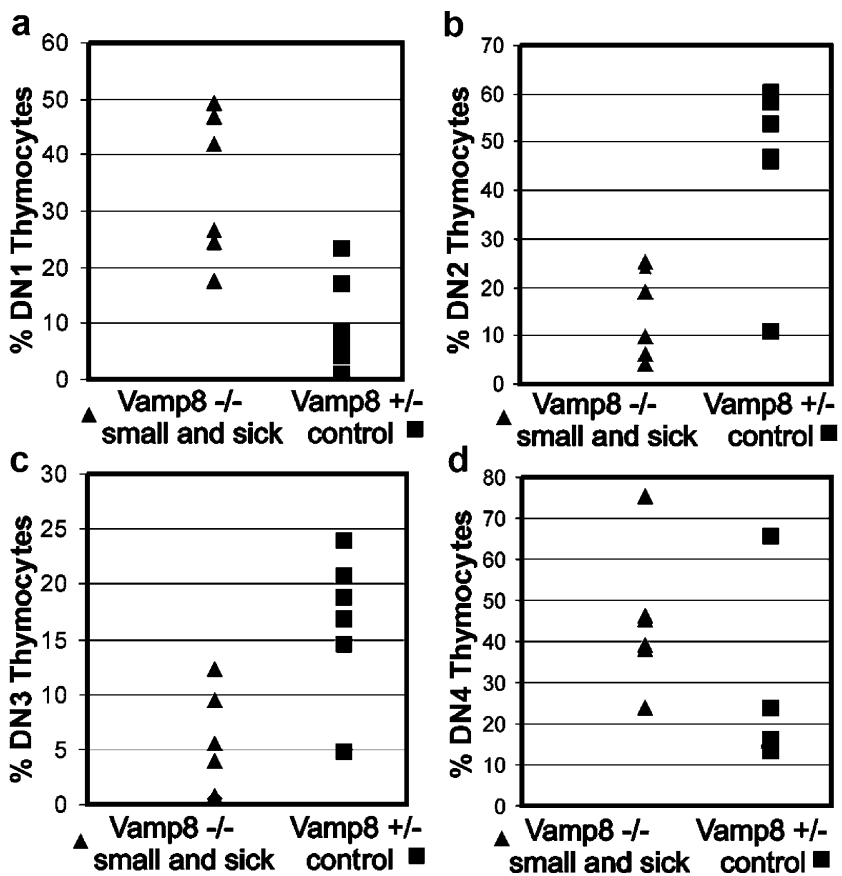

Fig. 6 VAMP8 deficiency led to a disturbance of DN thymocytes. A flow cytometric analysis of the DN precursor subsets in thymus of small and sick $\operatorname{Vamp~}^{-/-}$mice was performed. Lymphocytes were gated according to their light scattering characteristics, and the lineage marker negative cells were gated in a second step. The DN cells were further separated into DN1 to DN4 subsets depending upon the intensity of staining for CD44 and CD25 markers. A distribution plot shows a summary of six independent experiments (age: 10-12 days) comparing the DN1 (a), DN2, (b), DN3 (c), and DN4 (d) subsets of small and sick Vamp $8^{-/-}$mice and $\operatorname{Vamp} 8^{+/-}$littermates

the $\operatorname{Vamp}^{-/-}$lymphocyte progenitors are capable of differentiating into mature $\mathrm{T}$ lymphocytes, when introduced into an environment that is not VAMP8-deficient. This result suggests that the thymic environment is primarily affected by the VAMP8 deficiency.

\section{Discussion}

In the current study, we demonstrate that the SNARE protein VAMP8 is expressed in the thymus, and that its lack leads to an alteration of thymus cytoarchitecture and subsequently $\mathrm{T}$ cell development. This phenotype can be mild and transient but also severe and associated with early postnatal mortality; $36 \%$ of the $\operatorname{Vamp} 8^{-1-}$ mice died before reaching the age of 1 month.

The most severely affected $\operatorname{Vamp} 8^{-/-}$mice showed a characteristic developmental pattern, since they lost weight for 2-3 consecutive days before they eventually died. The VAMP8-deficient mice analyzed here were obtained by a gene trap strategy. A similar rate of early mortality (38\%) was observed in an independent Vamp 8 knockout line in which exon 2 was removed (Wang et al. 2004). In this previous study, VAMP8 was described to regulate the exocytosis of zymogen granules from pancreatic acinar cells (Wang et al. 2004). The VAMP8-deficient mice analyzed in the present study showed similar morphological alterations in the pancreas as reported by Wang et al. (2004). These data indicate that the gene trap mice used in this study display similar phenotypes as the knockout mice. However, alterations of thymus morphology and $\mathrm{T}$ cell development attributable to VAMP8 deficiency have not previously been described.

a

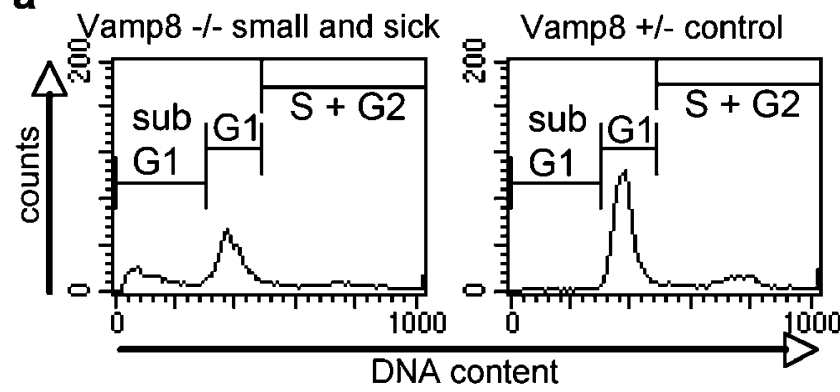

b

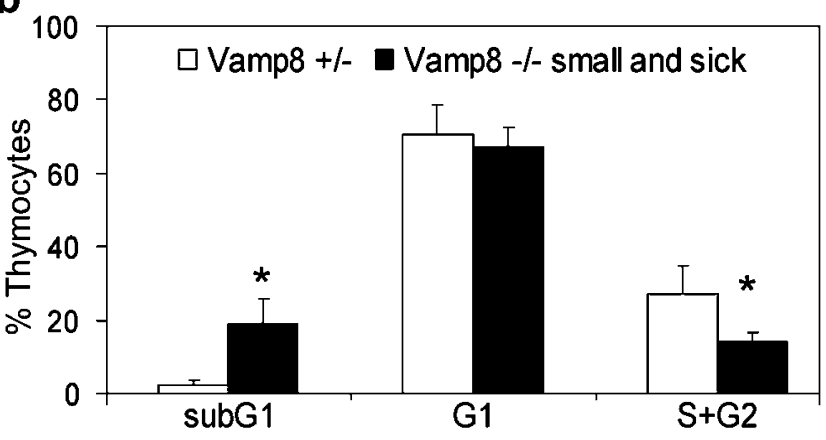

C

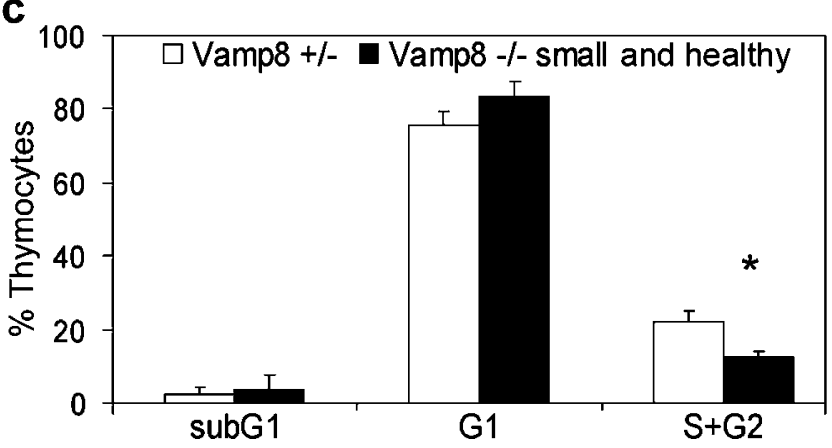

Fig. 7 Proportion of proliferating thymocytes was decreased in small and sick $\operatorname{Vamp} 8^{-/-}$mice. a DNA histograms of thymocytes of a small and sick $\operatorname{Vamp}^{-/-}$mouse and a $\operatorname{Vamp}^{+/-}$control mouse were obtained in a representative flow cytometric analysis. The percentage of proliferating thymocytes in the S and G2 phase is decreased in the Vamp $8^{-/}$mouse. In contrast, the proportion of apoptotic cells in the subG1 area is increased. b Summary of the cell cycle analysis of thymocytes obtained from small and sick $\operatorname{Vamp~}^{-/-}$mice and heterozygous littermates (bars percentage of thymocytes in cell cycle phases $1+\mathrm{SD} ; n=4$, age: $9-12$ days, $* P<0.05$, U test). c Thymi from small and healthy $\operatorname{Vamp} 8^{-/-}$mice $(n=4$, age: 9-12 days) show a reduced percentage of proliferating cells compared with heterozygous littermates $\left({ }^{*} P<0.05\right.$, U test $)$ 
Fig. 8 VAMP8 deficiency led to increased rates of apoptotic thymocytes. a-c TUNEL staining of apoptotic cells in thymus sections revealed a high number of apoptotic cells in a small and sick Vamp $8^{-/-}$mouse (12 days old, a) compared with a heterozygous mouse (8 days old, b). c A small and healthy Vamp $8^{--}$ littermate did not display increased apoptosis. Bars $20 \mu \mathrm{m}$. d Thymocytes of $\operatorname{Vamp~}^{-/-}$mice and heterozygous littermates were stained with annexin $\mathrm{V}$ and propidium iodide. Summary of the proportion of annexin-Vand propidium-iodide-negative viable cells among thymocytes from small and sick $(n=4)$, small and healthy $(n=3)$, and adult $(n=6) \operatorname{Vamp~}^{--}$mice and their heterozygous littermates is shown (bars percentage of viable thymocytes $\pm \mathrm{SD}$ ). The small and sick $\operatorname{Vamp} 8^{-1-}$ mice had significantly fewer viable thymocytes than their heterozygous littermates $(n=4, * P=0.02, \mathrm{U}$ test). e In a flow cytometric analysis, the percentage of annexin-V-positive apoptotic thymocytes was determined among the four major subpopulations defined by CD4 and CD8 markers (bars percentage of apoptotic thymocytes $1+\mathrm{SD}$ as determined in small and healthy $\operatorname{Vamp} 8^{-1-}$ mice and their heterozygous littermates; $n=3$ )
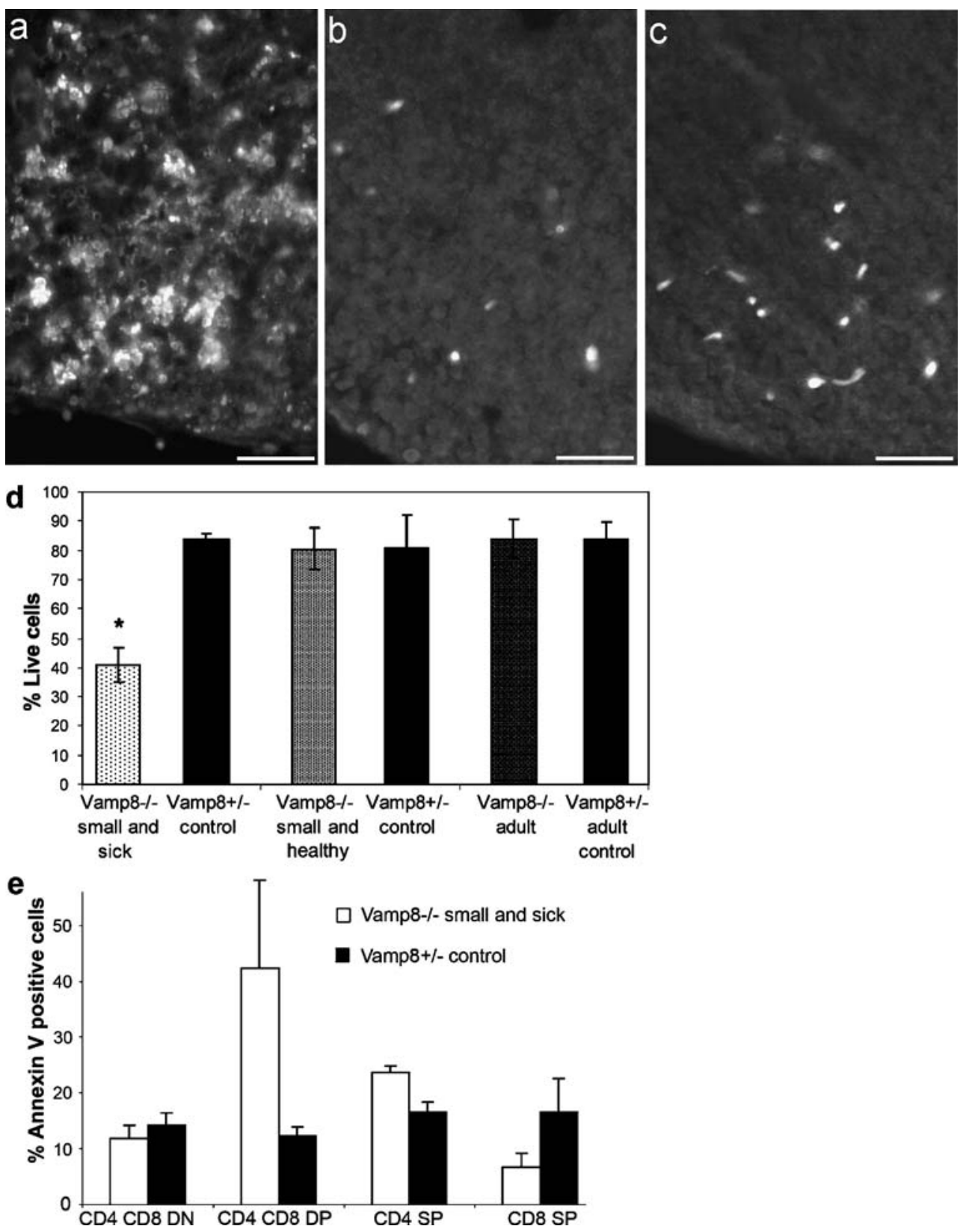

The most prominent thymic alterations were observed in Vamp $8^{-/-}$mice that had previously lost weight for 2-3 days, i.e., the small and sick mice. The size of the thymus and the number of thymocytes were significantly reduced in these mice. Importantly, the numbers of all major subpopulations of thymocytes decreased. Thus, both DN to DP and DP to mature SP transitions might be compromised in Vamp $8^{-/}$ mice. Since the DP cells were the most severely affected, the proportion of these cells was also dramatically reduced in contrast to the other populations. The size of the DP population is decided by a balance between the input from proliferating DN cells and the survival of DP cells dependent on positive selection. The finding of a major loss of DP thymocytes might argue for an impairment of positive selection of TCR-expressing cells that are able to recognize self-MHC molecules with their antigen receptor (Starr et al. 2003). However, the small and sick Vamp $8^{-/}$ mice expressed TCR, and the surface level on the TCR ${ }^{\text {low }}$ and $\mathrm{TCR}^{\text {high }}$ cell populations was not altered. The prominent shift toward $\mathrm{TCR}^{\text {high }}$ cells that was observed in Vamp $8^{-/-}$mice reflects the increased proportion of SP thymocytes in the affected mice.

The number of DN thymocytes was also reduced in the VAMP8-deficient mice. Mainly the CD25-positive DN2 and DN3 cells decreased among the DN thymocytes. At the DN3 stage, the thymocytes have to express a successfully 


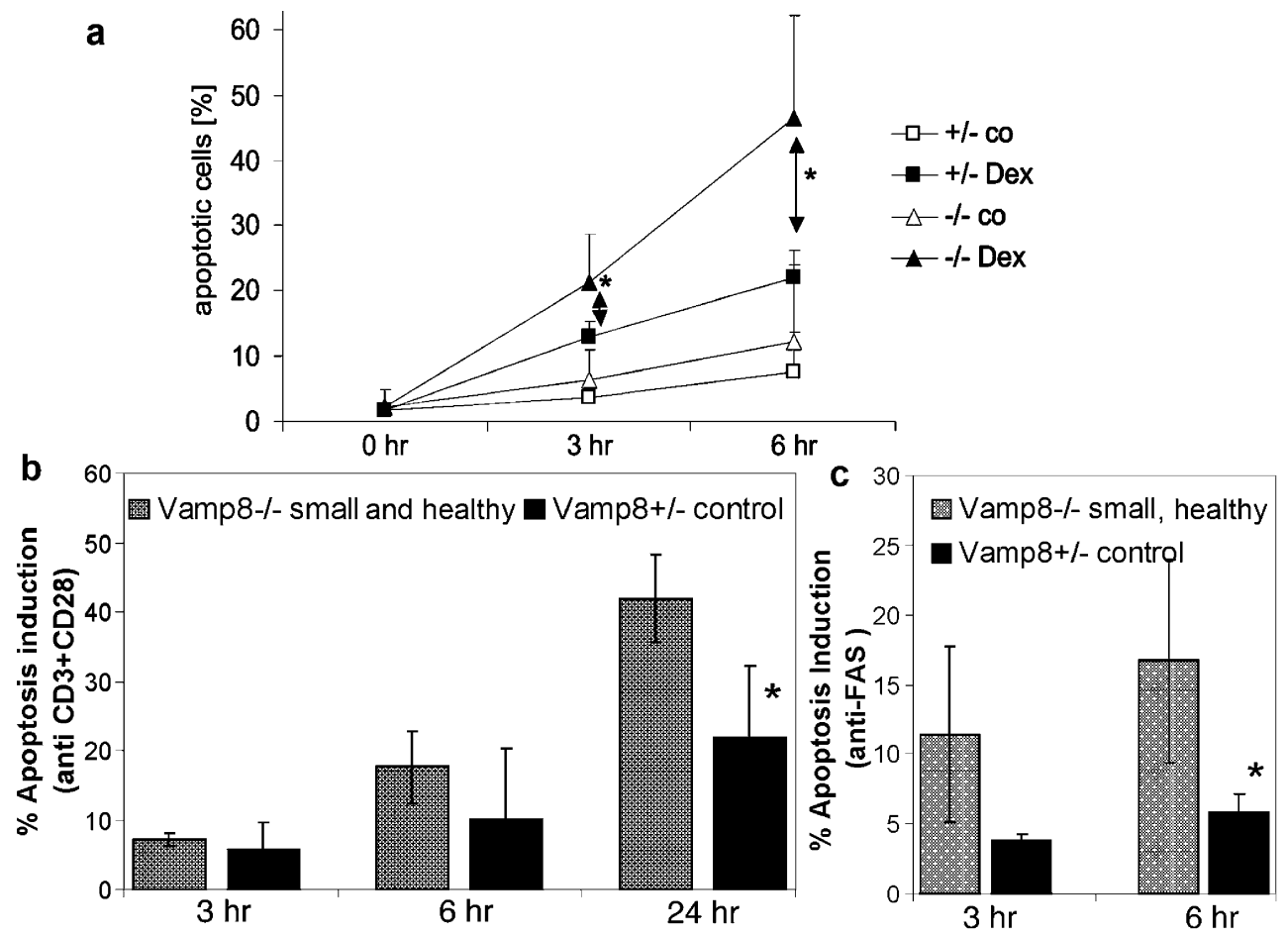

Fig. 9 Isolated thymocytes of small and healthy $\operatorname{Vamp} 8^{-/-}$mice were more susceptible to apoptosis induced in vitro. a Isolated thymocytes from small and healthy $\operatorname{Vamp} 8^{-/-}$mice and heterozygous littermates were cultured in vitro in the absence $(c o)$ or presence of $0.1 \mu \mathrm{M}$ dexamethasone (Dex) for $3 \mathrm{~h}$ and $6 \mathrm{~h}$ ( $h r$ hours). The proportion of apoptotic cells was determined by flow cytometry for DNA content after propidium iodide staining. A summary of the percentage of apoptosis in thymocytes from small and healthy $\operatorname{Vamp}^{-/-}$mice and heterozygous littermates is shown $\left(n=4\right.$, age: $8-13$ days, ${ }^{*} P<0.05, \mathrm{U}$ test). The data points indicate the percentage of subG1 thymocytes $1+$ SD. b Thymocytes from small and healthy $\operatorname{Vamp} 8^{-/-}$mice and heterozygous littermates were treated with $10 \mu \mathrm{g} / \mathrm{ml}$ anti-CD3 and

rearranged TCR $\beta$ chain together with the invariant preTCR $\alpha$ chain, otherwise they undergo apoptosis (Starr et al. 2003; Falk et al. 2001). The reduction of DN thymocytes might be caused by either a diminished proliferation or an increased rate of apoptosis.

The affected small and sick Vamp $8^{-/}$mice showed both a reduced proportion of proliferating cells and an increase in apoptotic cells. In flow cytometric analyses of annexin$\mathrm{V}$ - and propidium-iodide-stained thymocytes, only about $40 \%$ of the cells from small and sick $V a m p 8^{-/}$mice turned out to be alive. Most of the cells were positive for both annexin $\mathrm{V}$ and propidium iodide indicating a rapid progression of apoptosis.

As the affected small and sick Vamp $8^{-/-}$mice undergo severe stress, this makes it difficult to distinguish primary effects caused by VAMP8 deficiency from secondary effects occurring during the progression to death. Therefore, we next focused our analysis on the small and healthy animals. These mice had stopped gaining weight or lost some weight for 1 day but were otherwise normal and
anti-CD28 antibodies for various times and stained with annexin $\mathrm{V}$ and propidium iodide. The viable cells were quantified by flow cytometry. The induction of apoptosis was calculated as the difference between the live cells in the untreated and treated samples at each time point. A summary of the induction of apoptosis is shown $(n=4$, age: 8 days, $* P<0.05$, U test; bars percentage of thymocytes in which apoptosis was induced $\pm \mathrm{SD}$ ). c Thymocytes of small and healthy $\operatorname{Vamp} 8^{-/-}$mice and heterozygous littermates were treated with $1 \mu \mathrm{g}$ of an agonistic anti-FAS antibody (clone Jo2, BD Pharmingen). A summary of the induction of apoptosis is shown $(n=4$, age: 8 days, $* P<0.05$, $\mathrm{U}$ test; bars percentage of thymocytes in which apoptosis was induced $\pm \mathrm{SD}$ )

active. At this stage, the mice did not show any disturbance of thymocyte subsets, and the number of apoptotic thymocytes was not increased. However, a reduced proportion of proliferating cells in the thymus and a decreased number of thymocytes was detectable, even at this stage. Isolated thymocytes from these mice turned out to be more susceptible to apoptotic stimuli delivered in vitro. The rate of cell death was increased in response to glucocorticoids, to FAS receptor, and to $\mathrm{CD} 8 / \mathrm{CD} 28$-mediated signaling suggesting that different apoptotic pathways might be involved (Screpanti et al. 1989; Strasser and Bouillet 2003; Herold et al. 2006). Since the external apoptotic stimuli were delivered in the absence of the thymic stroma, the increased sensitivity of thymocytes to apoptosis might be a cell autonomous feature of VAMP8-deficient thymocytes. The epithelial phenotype of the mice might also depend on an intrinsic defect of the thymocytes. Thymocytes and stromal cells are known to cross-talk, so that their development is interdependent (van Ewijk et al. 2000; Rodewald 2008), 
Fig. 10 Bone marrow of small and sick $\operatorname{Vamp} 8^{-/}$mice was able to repopulate $\operatorname{Rag} 2^{-/-} \gamma \mathrm{c}^{-/-}$ mice with peripheral $\mathrm{T}$ lymphocytes. Bone marrow cells $\left(1 \times 10^{6}\right)$ from 10 -day-old small and sick Vamp $8^{-/-}$mice $(\mathbf{b}, \mathbf{e}, \mathbf{h})$ or $\operatorname{Vamp}^{+/-}$littermates (c, f, h) were injected intravenously into irradiated $\operatorname{Rag}^{-/-} \gamma \mathrm{c}^{-/-}$mice. Control Rag2 $2^{-/-} \gamma c^{-/-}$mice were not transplanted (a, d, g). At 7 weeks after transplantation, blood samples were obtained from the recipients and analyzed for the presence of $\mathrm{B}$ and $\mathrm{T}$ lymphocytes by flow cytometry with antibodies against CD4 and CD3 (a-c) or CD8 and CD3 (df) for the $T$ lymphocytes and against B220 and CD19 for the B lymphocytes (g-i). The progenitor cells from small and sick Vamp $8^{-1-}$ mice gave rise to $\mathrm{B} 220^{+} \mathrm{CD} 19^{+}$B-lymphocytes (h) and $\mathrm{CD}^{+} \mathrm{CD}^{+}(\mathbf{e})$ and $\mathrm{CD}^{+} \mathrm{CD}^{+}$(b) $\mathrm{T}$ lymphocytes similarly to progenitor cells from the $\operatorname{Vamp} 8^{+/-}$bone marrow $(\mathbf{i}, \mathbf{f}, \mathbf{c})$
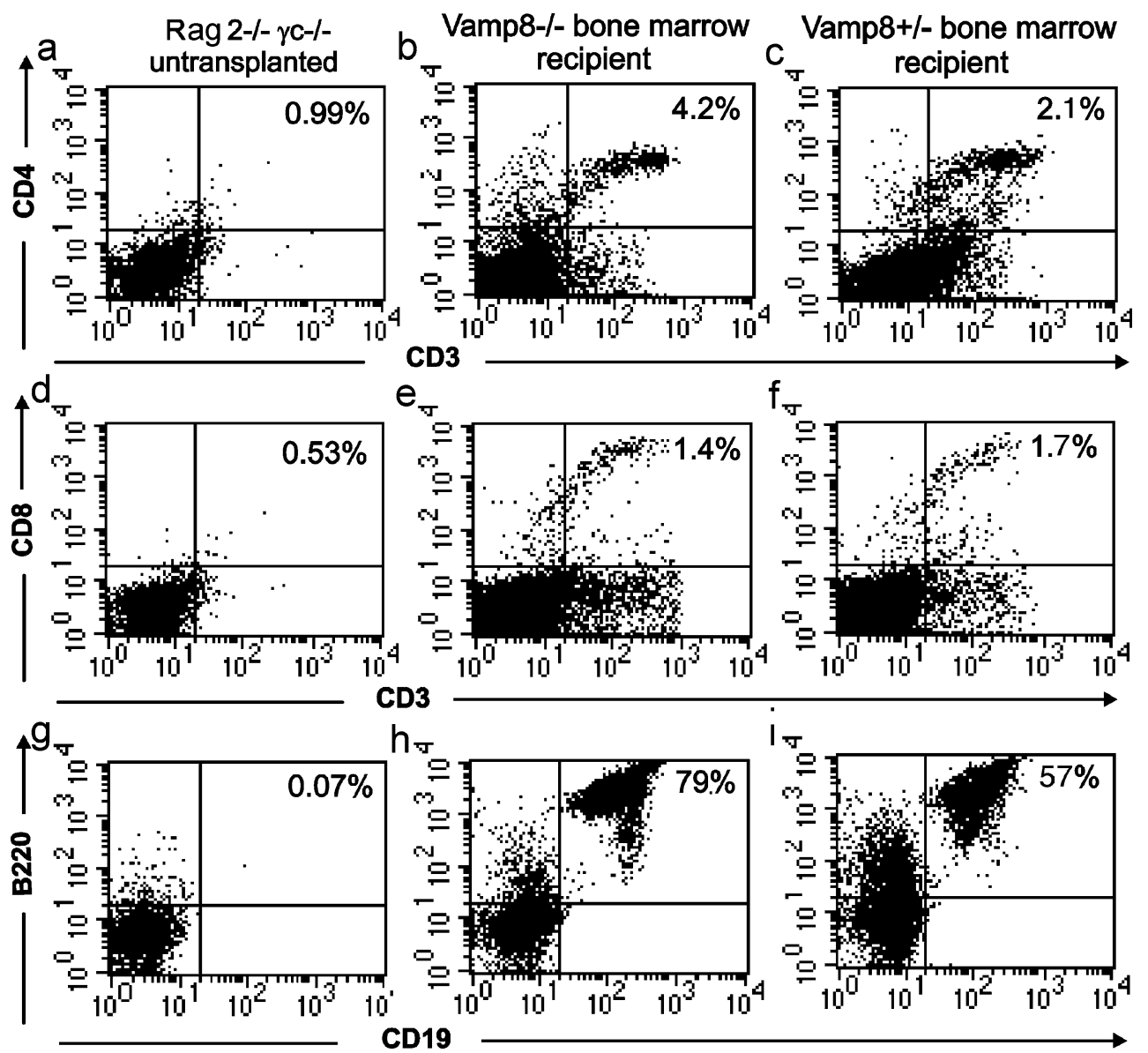

On the other hand, not only the small and sick, but also the small and healthy $\operatorname{Vamp} 8^{-1-}$ mice demonstrated a disturbed histological architecture, as seen in HE-stained tissue sections, but more specifically when the distribution of cTEC and mTEC was analyzed by keratin 5 and keratin 8 staining. Thus, the increased sensitivity of thymocytes to apoptosis in these mice could alternatively be caused by inappropriate conditioning by the VAMP8-deficient stroma as has been reported, for example, in mice with a STAT3 deficiency in the thymic epithelia only (Sano et al. 2001).

To address this question, bone marrow transplantations were performed. Bone marrow cells derived from small and sick $\operatorname{Vamp}^{-/-}$mice with a clear phenotype and severe thymic alterations were readily able to repopulate $\operatorname{Rag} 2^{-/-} \gamma c^{-/-}$mice and gave rise to normal peripheral $\mathrm{T}$ lymphocytes. Thus, the development of the thymic phenotype appears to depend on the environment. The disorganized VAMP8-deficient stromal cells appear to be impaired in their ability to support $\mathrm{T}$ cell development. Therefore, the VAMP8 deficiency appears to disturb the organization of the thymic epithelium thereby reducing the proliferation of thymocytes and increasing their sensitivity to apoptotic stimuli. During the progression of the phenotype, increasing numbers of apoptotic thymo- cytes were observed in situ and ex vivo, and the DP developmental stage of the thymocytes was most severely reduced. The molecular pathway that is affected in the thymus of the $V a m p 8^{-/-}$mice leading to a disturbed organization of the thymic epithelium remains unknown. Given the fundamental role of SNARE proteins in the transport of vesicles and cargo, numerous cellular pathways in the thymic stroma might be affected by VAMP8 deficiency.

How can the incomplete penetrance in the phenotype of the $V a m p 8^{-1-}$ mice be explained? Since the mice were maintained on a mixed genetic background, modifier genes, which differ in the C57BL/6 and 129SvJ strains, might influence the phenotype. Importantly, a similar reduced penetrance with respect to early mortality has been observed in a completely independent Vamp8 knockout model (Wang et al. 2004). We also have no indication that external factors are responsible for the variation, since we have always analyzed littermates. We did not observe any variations that could depend, for example, on the fitness of the individual animals to compete for feeding. The affected mice were not more frequent in large litters in which feeding might be more limited for weaker animals 
compared with small litters. Furthermore, heterozygous females were used for breading to exclude possible secondary effects attributable to the quality of nursing given by the VAMP8-deficient mothers. Vamp $8^{-/-}$mice might undergo a phase of reduced proliferation of thymocytes and increased susceptibility to apoptosis between days 8 and 12. This phase might not be critical without additional effects aggravating the thymic phenotype and leading to death. Thus, a stochastic phenomenon might influence whether an individual animal is affected so severely by the general effects of VAMP8 deficiency that recovery and survival are not possible.

SNARE proteins are known to mediate important functions in the immune system, e.g., during phagocytosis, secretion of cytokines, and degranulation of immune cells (Stow et al. 2006). The family member VAMP8 appears to have a unique function in the thymus for the organization of the thymic epithelial cells and subsequently for the proliferation and apoptosis of developing $\mathrm{T}$ lymphocytes. VAMP8 is the first SNARE protein shown to have such a specific function in the thymus and during T cell development. The molecular pathways in which VAMP8 is involved within thymocytes remain to be elucidated. Knowledge of these pathways is needed if we are to understand how VAMP8 deficiency affects the organization of the microenvironment in the thymus.

Acknowledgements The expert technical assistance of Beate Veith, Christiane Wiegand, and Leslie Elsner is gratefully acknowledged. The authors thank Prof. J. Wienands and Prof. H. Reichardt, Department of Cellular and Molecular Immunology, University of Göttingen, for helpful discussions. The $\operatorname{Rag}^{-/-} \gamma c^{-/-}$mice were kindly provided by Prof. J. Wienands.

\section{References}

Advani RJ, Bae HR, Bock JB, Chao DS, Doung YC, Prekeris R, Yoo JS, Scheller RH (1998) Seven novel mammalian SNARE proteins localize to distinct membrane compartments. J Biol Chem 273:10317-10324

Antonin W, Holroyd C, Fasshauer D, Pabst S, Fischer von Mollard G, Jahn R (2000a) A SNARE complex mediating fusion of late endosomes defines conserved properties of SNARE structure and function. EMBO J 19:6453-6464

Antonin W, Riedel D, Fischer von Mollard G (2000b) The SNARE Vtila-beta is localized to small synaptic vesicles and participates in a novel SNARE complex. J Neurosci 20:5724-5732

Atlashkin V, Kreykenbohm V, Eskelinen EL, Wenzel D, Fayyazi A, Fischer von Mollard G (2003) Deletion of the SNARE vtilb in mice results in the loss of a single SNARE partner, syntaxin 8 . Mol Cell Biol 23:5198-5207

Bordier C (1981) Phase separation of integral membrane proteins in Triton X-114 solution. J Biol Chem 256:1604-1607

Cao XQ, Shores EW, Huli J, Anver MR, Kelsall BL, Russell SM, Drago J, Noguchi M, Grinberg A, Bloom ET, Paul WE, Katz SI,
Love PE, Leonard WJ (1995) Defective lymphoid development in mice lacking expression of the common cytokine receptorgamma chain. Immunity 2:223-238

Dressel R, Elsner L, Quentin T, Walter L, Günther E (2000) Heat shock protein 70 is able to prevent heat shock-induced resistance of target cells to CTL. J Immunol 164:2362-2371

Egerton M, Scollay R, Shortman K (1990) Kinetics of mature T-cell development in the thymus. Proc Natl Acad Sci USA 87:25792582

Ewijk W van, Hollander G, Terhorst C, Wang B (2000) Stepwise development of thymic microenvironments in vivo is regulated by thymocyte subsets. Development 127:1583-1591

Falk I, Nerz G, Haidl I, Krotkova A, Eichmann K (2001) Immature thymocytes that fail to express TCR beta and/or TCR gamma delta proteins die by apoptotic cell death in the CD44(-)CD25(-) (DN4) subset. Eur J Immunol 31:3308-3317

Fayyazi A, Eichmeyer B, Soruri A, Schweyer S, Herms J, Schwarz P, Radzun HJ (2000) Apoptosis of macrophages and $\mathrm{T}$ cells in tuberculosis associated caseous necrosis. J Pathol 191:417-425

Franke WW, Schiller DL, Moll R, Winter S, Schmid E, Engelbrecht I, Denk H, Krepler R, Platzer B (1981) Diversity of cytokeratinsdifferentiation specific expression of cytokeratin polypeptides in epithelial-cells and tissues. J Mol Biol 153:933-959

Godfrey DI, Kennedy J, Suda T, Zlotnik A (1993) A developmental pathway involving 4 phenotypically and functionally distinct subsets of CD3-CD4-CD8-triple-negative adult-mouse thymocytes defined by CD44 And CD25 expression. J Immunol 150:4244-4252

Herold MJ, McPherson KG, Reichardt HM (2006) Glucocorticoids in $\mathrm{T}$ cell apoptosis and function. Cell Mol Life Sci 63:60-72

Hogquist KA, Baldwin TA, Jameson SC (2005) Central tolerance: learning self-control in the thymus. Nat Rev Immunol 5:772-782

Kisielow P, Teh HS, Bluthmann H, Vonboehmer H (1988) Positive selection of antigen-specific T-cells in thymus by restricting Mhc molecules. Nature 335:730-733

Klug DB, Carter C, Crouch E, Roop D, Conti CJ, Richie ER (1998) Interdependence of cortical thymic epithelial cell differentiation and T-lineage commitment. Proc Nat Acad Sci USA 95:1182211827

Jahn R, Scheller RH (2006) SNAREs - engines for membrane fusion. Nat Rev Mol Cell Biol 7:631-643

Kreykenbohm V, Wenzel D, Antonin W, Atlachkine V, Fischer von Mollard G (2002) The SNAREs vtila and vtilb have distinct localization and SNARE complex partners. Eur J Cell Biol 81:273-280

Lippert U, Ferrari DM, Jahn R (2007) Endobrevin/VAMP8 mediates exocytotic release of hexosaminidase from rat basophilic leukaemia cells. FEBS Lett 581:3479-3484

Ormerod MG, Collins MK, Rodriguez-Tarduchy G, Robertson D (1992) Apoptosis in interleukin-3-dependent hematopoietic-cells -quantification by 2 flow cytometric methods. J Immunol Methods 153:57-65

Perret E, Lakkaraju A, Deborde S, Schreiner R, Rodriguez-Boulan E (2005) Evolving endosomes: how many varieties and why? Curr Opin Cell Biol 17:423-434

Polo S, Di Fiore PP (2006) Endocytosis conducts the cell signaling orchestra. Cell 124:897-900

Pryor PR, Mullock BM, Bright NA, Lindsay MR, Gray SR, Richardson SCW, Stewart A, James DE, Piper RC, Luzio JP (2004) Combinatorial SNARE complexes with VAMP7 or VAMP8 define different late endocytic fusion events. EMBO Reports 5:590-595

Ren QS, Barber HK, Crawford GL, Karim ZA, Zhao CX, Choi WS, Wang CC, Hong WJ, Whiteheart SW (2007) Endobrevin/VAMP8 is the primary v-SNARE for the platelet release reaction. Mol Biol Cell 18:24-33 
Rodewald HR (2008) Thymus organogenesis. Annu Rev Immunol $26: 355-388$

Sano S, Takahama Y, Sugawara T, Kosaka H, Itami S, Yoshikawa K, Miyazaki J, Ewijk W van, Takeda J (2001) Stat3 in thymic epithelial cells is essential for postnatal maintenance of thymic architecture and thymocyte survival. Immunity 15:261-273

Screpanti I, Morrone S, Meco D, Santoni A, Gulino A, Paolini R, Crisanti A, Mathieson BJ, Frati L (1989) Steroid sensitivity of thymocyte subpopulations during intrathymic differentiation. Effects of 17 beta-estradiol and dexamethasone on subsets expressing $\mathrm{T}$ cell antigen receptor or IL-2 receptor. J Immunol 142:3378-3383

Starr TK, Jameson SC, Hogquist KA (2003) Positive and negative selection of T cells. Annu Rev Immunol 21:139-176

Stow JL, Manderson AP, Murray RZ (2006) SNAREing immunity: the role of SNAREs in the immune system. Nat Rev Immunol 6:919929

Strasser A, Bouillet P (2003) The control of apoptosis in lymphocyte selection. Immunol Rev 193:82-92
Sutton RB, Fasshauer D, Jahn R, Brunger AT (1998) Crystal structure of a SNARE complex involved in synaptic exocytosis at $2.4 \AA$ resolution. Nature 395:347-353

Takahama Y (2006) Journey through the thymus: stromal guides for T-cell development and selection. Nat Rev Immunol 6:127-135

Thien CB, Blystad FD, Zhan Y, Lew AM, Voigt V, Andoniou CE, Langdon WY (2005) Loss of c-Cbl RING finger function results in high-intensity TCR signaling and thymic deletion. EMBO J 24:3807-3819

Wang CC, Ng CP, Lu L, Atlashkin V, Zhang W, Seet LF, Hong W (2004) A role of VAMP8/endobrevin in regulated exocytosis of pancreatic acinar cells. Dev Cell 7:359-371

Wang CC, Shi H, Guo K, Ng CP, Li J, Gan BQ, Liew HC, Leinonen J, Rajaniemi H, Zhou ZH, Zeng Q, Hong WJ (2007) VAMP8/ endobrevin as a general vesicular SNARE for regulated exocytosis of the exocrine system. Mol Biol Cell 18:1056-1063

Zambrowicz BP, Friedrich GA, Buxton EC, Lilleberg SL, Person C, Sands AT (1998) Disruption and sequence identification of 2,000 genes in mouse embryonic stem cells. Nature 392:608-611 